\title{
Clinical and biological significance of aneuploidy in human tumours
}

\author{
MICHAEL L FRIEDLANDER, DAVID W HEDLEY, IAN W TAYLOR \\ From the Ludwig Institute for Cancer Research (Sydney Branch), Blackburn Building, University of Sydney, \\ Sydney, New South Wales 2006, Australia
}

SUMMARY Aneuploidy is a well recognised feature of human tumours, but the investigation of its biological and clinical significance has been hampered by technological constraints. Quantitative DNA analysis reflects the total chromosomal content of tumour cells and can now be determined rapidly and reliably using flow cytometry; this has resulted in renewed interest in its potential clinical applications. This article reviews the accumulating evidence that tumour ploidy reflects the biological behaviour of a large number of tumour types and that diploid tumours in particular have a relatively good prognosis. The measurement of tumour ploidy is likely to become a valuable adjunct to the clinical and histopathological assessment of cancers.

Recent advances in the field of molecular genetics suggest that a critical early step in the initiation of at least some cancers is a chromosomal rearrangement which alters the expression of certain structural genes, the so called c-onc genes, the result being a change in the cell's responsiveness to normal growth control mechanisms. ${ }^{1-7}$ Karyotypic abnormalities have long been recognised in established human cancers, ${ }^{8}$ and here the chromosomes that are most commonly affected contain some of the genes regulating metabolism and nucleic acid synthesis. ${ }^{9-12}$ The gains or losses of such chromosomes alter the amount of specific cell products, ${ }^{13}$ and if these are critical for the control of cell division and differentiation the resulting cells may achieve a proliferative advantage. Furthermore, genetic rearrangements may increase the rate of spontaneous mutation in a cell line ${ }^{14}$ and allow the more rapid progression to a highly malignant phenotype..$^{15} 16$

The haematological malignancies have proved to be the most productive area for studying cytogenetic abnormalities in human cancer. ${ }^{17-21}$ Major landmarks include the demonstration of a specific marker chromosome for chronic myeloid leukaemia, ${ }^{22}{ }^{23}$ the finding that certain chromosomal

Accepted for publication 10 May 1984 abnormalities or defects of DNA repair are associated with an increased susceptibility to acute leukaemia, ${ }^{24} 25$ and, more recently, the identification in some patients with Burkitt's lymphoma of an 8:14 translocation involving the homologue of a known mouse oncogene, c-myc. ${ }^{26}$ When applied to the more common carcinomas, cytogenetics has been less successful; a major technical problem is the scarcity of assessible chromosome spreads. ${ }^{27} \mathrm{~A}$ more fruitful approach has been the cytometric measurement of total cellular DNA content. With the exception of some highly specialised research methods ${ }^{28}$ cytometry does not give any information about detailed chromosome structure. But it has the advantages of being applicable to interphase cells and of allowing sufficient cells to be examined for statistical analysis of cell cycle phase distribution. ${ }^{29}$ Early studies using static cytometry showed a high incidence of abnormalities of cellular DNA content in the common solid tumours, ${ }^{30}$ while the more recent introduction of flow cytometry has made routine examination of clinical samples a practical proposition..$^{2931}$ Numerous studies correlating abnormalities of cellular DNA content with clinical behaviour have either been reported or are in progress, and because this interest coincides with major advances in understanding the genetic basis of cancer it is timely to review the findings. 


\section{Material and methods}

There are a number of comprehensive reviews which adequately cover the practical and technical aspects of flow cytometry, ${ }^{2931}$ static cytometry, ${ }^{32} 33$ and chromosomal analysis. ${ }^{34} 35$ We will therefore cover only briefly the basic principles and advantages and disadvantages of these different techniques.

\section{CHROMOSOMAL ANALYSIS}

Chromosome studies require that the tumour is initially disaggregrated by mechanical or enzymatic techniques. The resulting single cell suspension is then exposed to a mitotic inhibitor, swelled in a hypotonic solution, and fixed, and then the chromosomes are spread on glass slides. The interaction of alkylating fluorochromes (for example, quinacrine mustard) and histochemical stains (for example, Giemsa) with specific regions of chromosomes produces multiple characteristic bands which can be identified on the metaphase chromosomes. ${ }^{36}$ Recent refinements using high resolution banding techniques have shown that these wide dark and light bands are composed of a number of narrower bands, which further enhance the identification of chromosomal rearrangements in cells. ${ }^{37}$

The normal human somatic cell with 46 chromosomes ( 23 pairs) is referred to as diploid, ${ }^{38}$ while a cell with fewer or more than 46 chromosomes is described as aneuploid (hypodiploid or hyperdiploid, respectively) and a cell with a balanced gain or loss of chromosomes, or with structural rearrangements, that still has 46 chromosomes is pseudodiploid. Most established tumours can be characterised by a modal chromosome number which tends to fall into either a near diploid or triploid-tetraploid mode. Within the diploid range, chromosome numbers can vary from 40 to 50 , but malignant tumours can have the normal diploid component of 46 chromosomes. ${ }^{39}$ High chromosome numbers may be achieved by a doubling of the complete chromosome set through several mechanisms such as nondysjunction, endoreduplication, or cell fusion.$^{40}$ Tumours with a modal DNA number in the triploid-tetraploid range do not always have marker chromosomes present in duplicate, which suggests that chromosome loss has occurred subsequent to doubling. ${ }^{41}$

Although chromosomal analysis is applicable to leukaemias, the analysis of solid tumours poses more difficult problems and in only $10-20 \%$ of cases can interpretable chromosome spreads be obtained. For this reason there are few detailed karyotypic studies of human solid tumours, and the published data tend to be biased towards those tumours which are technically favourable - that is, those which have a high mitotic rate and yield a proportion of well spread metaphases. ${ }^{8}$

QUANTITATIVE DNA ANALYSIS

Identification of individual chromosomes is possible only during metaphase, whereas cellular DNA content can be determined on interphase cells independent of the proliferative activity of the tumour. ${ }^{29}$ The detection of a chromosomal abnormality by means of cellular DNA content is a function of its relative frequency within the population studied, the amount of aberrant chromosome material involved, and the resolution of the technique used. There may be a wide scattering of chromosome numbers about a modal number in certain tumours that have constant DNA packaging, ${ }^{42}$ but technical factors such as disruption of metaphases during chromosome spreading should also be taken into account $t^{43}$ because a linear relation between chromosome number and DNA content has often been found. .3-47 $^{43}$

Quantitative measurement of cellular DNA content has been by one of two procedures. The Feulgen-Schiff technique entails removal of the purines from DNA by acid hydrolysis and the subsequent reaction of the exposed aldehyde groups of deoxyribose sugars with aldehyde specific Schiff reagents. Such reagents may be strongly coloured, such as pararosaniline, or fluorescent, such as acriflavine ${ }^{4849}$ The second method of measuring cellular DNA content relies on the use of fluorescent dyes which bind directly to DNA. Some of these, such as ethidium bromide and propidium iodide, intercalate with double stranded nucleic acids and therefore require the removal of RNA; others, such as DAPI (4'6-diamindio-2-phenylindol-dichloride) and mithramycin, react with specific moieties in DNA. ${ }^{29}$ All these stains bind to normal DNA stoichiometrically - that is, the degree of staining is directly proportional to the amount of DNA. The DNA content of individual cells can then be measured using either static cytometry or, more recently, flow cytometry.

\section{STATIC CYTOMETRY}

Both the above staining techniques have been employed in static cytometry, in which stained single cells are visualised by a microscope based system and the amount of DNA bound dye measured directly by absorption or fluorimetric means. ${ }^{48-50}$ Fig. 1 shows the distribution of the cellular DNA content of a tumour obtained in this way. This technique is applicable to the analysis of histological sections of formalin fixed tissue or fixed smear preparations from tumours, where the DNA content of morphologically identified tumour cells can be determined. Leucocytes and normal epithelium pre- 


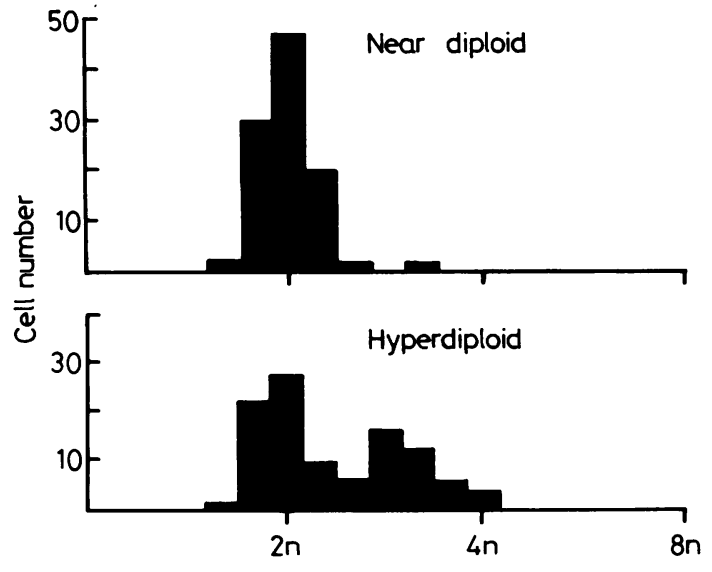

Fig. 1 DNA distribution pattern of a near diploid and hyperdiploid tumour obtained using static cytometry. The $D N A$ values are expressed in relation to the median of the DNA values ( $2 n)$ of the internal diploid control cells. The resolution of this technique and the number of cells analysed should be compared with the histograms obtained using flow cytometry in Fig. 2.

sent in the tissue section are used as a normal diploid control. Owing to the relatively slow data acquisition rates of this procedure, however, measurement of DNA content is usually restricted to several hundred cells in any one sample.

\section{FLOW CYTOMETRY}

In contrast to static cytometry, flow cytometry is characterised by high precision and speed of sample handling. ${ }^{29}$ A single cell or nuclear suspension prepared from a sample of tumour is stained with DNA specific fluorochromes and examined at rates of about 1000 cells per second. ${ }^{5152}$ Typical DNA histograms containing between 10 and 30000 cells are shown in Fig. 2. In this instance chicken red blood cells were used as an internal standard to identify the diploid peak. A number of different standards such as human lymphocytes or trout erythrocytes can be used. ${ }^{5354}$

\section{CELLULAR DNA CONTENT}

Most solid tumours contain a population of cells with a diploid DNA content, ${ }^{55}$ and when this is the only cell population present the tumour is classified as diploid. Tumours which have evidence of an additional $G_{1}$ peak are classified as aneuploid, and the diploid peak is assumed to comprise host cells such as lymphocytes and stroma. In most instances this assumption holds true, although there are occasions where in aneuploid tumours the diploid component may also contain malignant cells. ${ }^{56}{ }^{57}$ Most aneuploid tumours contain only a single aneuploid $G_{1}$ peak, but when there is clear evidence of more than one
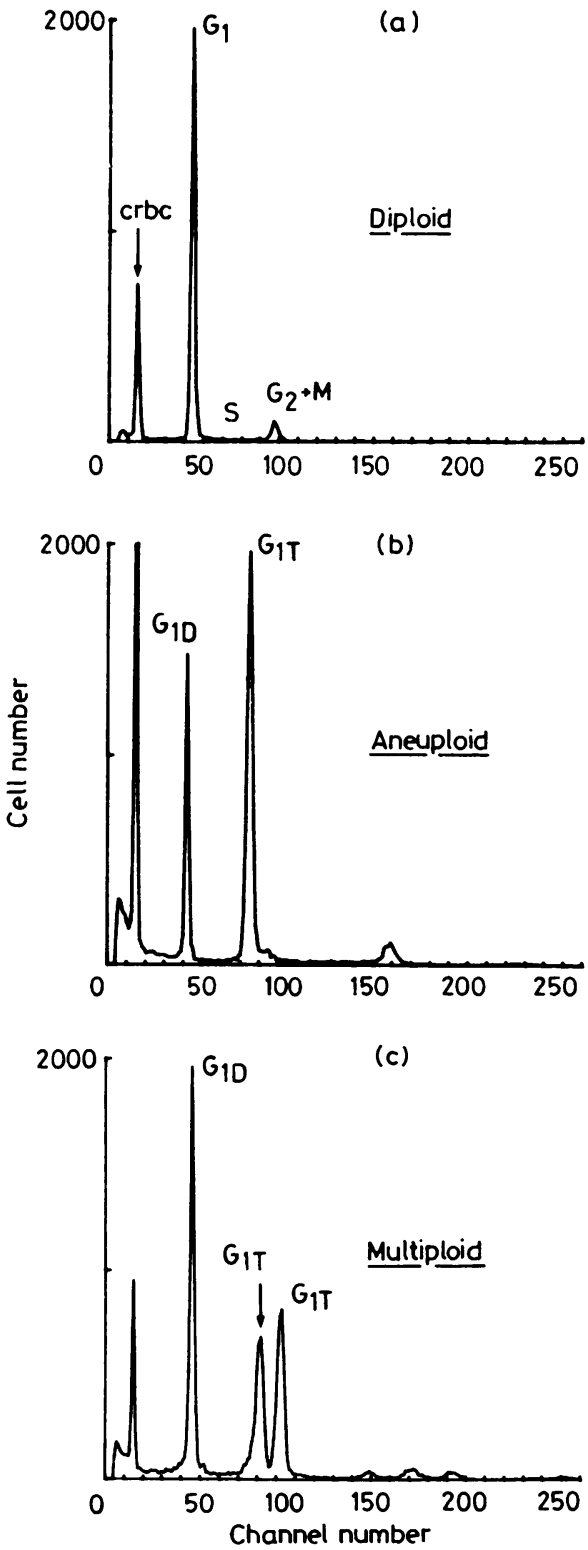

Fig. 2 Representative DNA histograms obtained from solid tumours using flow cytometry. Channel number represents relative fuorescence intensity, which is directly proportional to DNA content. Numbers of cells are shown on the ordinate. Chicken red blood cells (crbc) are used as an internal biological standard to identify the diploid $G_{1}$ peak $\left(G_{1 D}\right)$ (see text). Most tumours contain a population of cells with diploid DNA content and when this is the only population present the tumour is classified as diploid (a). Tumours which have evidence of an additional $G_{1}$ peak $\left(G_{1 T}\right)$ are classified as single aneuploid $(b)$, and when there is clear evidence of more than one tumour $G_{1}$ peak the tumour is classified as multiploid (c). 
aneuploid $G_{1}$ peak the tumour is considered to be multiploid. These terms are not synonymous with chromosome number, and although in most instances a good correlation exists between chromosome number and cellular DNA content, ${ }^{43-47}$ the resolution using flow cytometry is such that gains or losses of one or two chromosomes would not be detected. ${ }^{58}$

The varying degrees of aneuploidy can be quantitated by the DNA index, which represents the ratio of the DNA content of tumour $G$ cells to the diploid $G_{1}$ peak. Thus a DNA index of 1 is synonymous with a diploid ( $2 n$ ) DNA content and a DNA index of 1.5 represents cells with a triploid ( $3 \mathrm{n})$ DNA content. ${ }^{\text {ss }}$

Studies in a variety of tumour types have shown a bimodal distribution of DNA content, with tumours having either a near diploid mode or a triploidtetraploid mode ${ }^{5559}$ (Fig. 3). The interpretation of cellular DNA content varies considerably in different studies, with some investigators classifying those tumours with a DNA index of less than 1.5 as near diploid and tumours which have a DNA index of greater than 1.5 as hyperdiploid. While this fairly crude cut off was required with static cytometry the improved resolution with flow cytometry makes it possible to determine the biological importance of diploid tumours (DNA index $=1$ ), and tumours containing multiple cell lines with different ploidies can be better identified.

With few notable exceptions, the available data suggest that most tumours exhibit stability of ploidy both spatially and temporally. ${ }^{55}{ }^{59-63}$ Regional variations in tumour ploidy do occur in colonic cancer, ${ }^{64}$ small cell lung cancer, ${ }^{65}$ melanoma, ${ }^{57}$ and brain tumours. ${ }^{.6}$ Chromosomal studies have, in general, supported these flow cytometric findings, with the finding of mosaicism in certain tumours and relative karyotypic stability in the majority of tumours. ${ }^{8}$ The genesis of a completely new karyotype is extremely uncommon, and when changes are evident they are usually minor with the basic karyotypic picture remaining unchanged..$^{39}$

There is a good correlation between the DNA content as determined with static cytometry and flow cytometry, ${ }^{6768}$ and studies of the cellular DNA content of solid tumours determined with both methods will be reviewed. Because static cytometry is applicable to paraffin embedded tumour tissue a number of studies have been done on groups of patients in whom the outcome was known, whereas flow cytometry has been restricted to fresh tumour tissue with long term follow up necessary to determine the prognostic importance of cellular DNA content. Recently, however, a flow cytometric method for determining cellular DNA content of paraffin embedded tissue has been described ${ }^{69}$

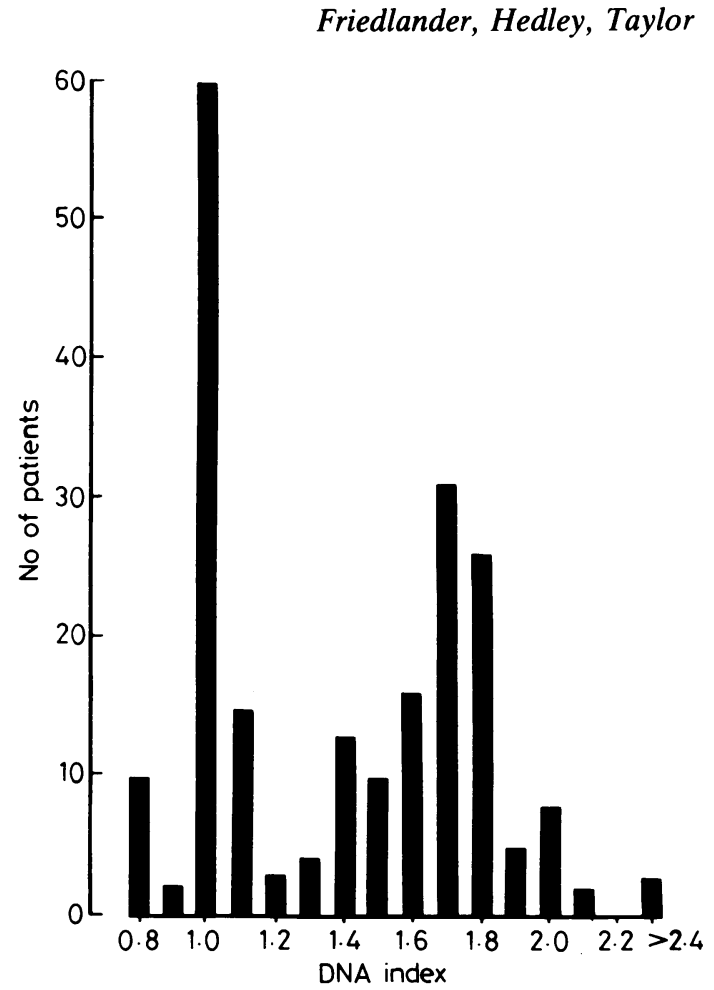

Fig. 3 Frequency histogram showing the bimodal distribution of tumour ploidy in breast cancer. Ploidy measurements were made using flow cytometry and are expressed as DNA index, which represents the ratio of the $D N A$ content of tumour $G_{1}$ cells to the diploid $G_{1}$ peak. $A$ $D N A$ index of 1 is synonymous with a diploid (2n) DNA content.

which, like static cytometry, allows retrospective analysis of tumours from groups of patients whose outcome is known, but with the added advantage that large numbers of cells can be analysed rapidly.

\section{Clinical and biological significance of tumour ploidy}

\section{HAEMATOLOGICAL MALIGNANCIES}

Chromosomal analysis is now recognised to be of value in the management of patients with haematological malignancies 217071 and is particularly useful in the diagnosis of chronic granulocytic leukaemia ${ }^{22} 23$ and Burkitt's lymphoma ${ }^{1}$ and in the identification of different prognostic subsets within the acute leukaemias. ${ }^{2070-72}$ Only the studies relating to ploidy will be presented here, however, as there is a large number of excellent and comprehensive reviews on the cytogenetics of leukaemias and lymphomas. 1821707173

Aneuploidy occurs in up to $20 \%$ of cases of acute myelocytic leukaemia and $30 \%$ of cases of acute lymphocytic leukaemia, which is somewhat lower than the reported incidence using chromosome 
analysis and banding. ${ }^{19707174-76}$ Notwithstanding, the flow cytometric determination of tumour ploidy has been reported to be a useful investigation in acute leukaemia. ${ }^{7-78}$ In childhood acute lymphoblastic leukaemia there is a significant association between tumour ploidy and other recognised prognostic features such as the expression of differentiation antigens, age, sex, and initial white cell count. $^{76-78}$ Patients with aneuploid acute lymphoblastic leukaemia have a better prognosis, an improved response rate to chemotherapy, and a longer duration of remission than those patients with diploid acute lymphoblastic leukaemia..$^{77}$ Similar findings have been reported from chromosome studies in acute lymphoblastic leukaemia, where patients with more than 50 chromosomes detected in the marrow had a significantly improved prognosis..$^{20}$ In contrast, in acute myelocytic leukaemia the presence of aneuploidy is associated with a relatively bad prognosis and a lower response to chemotherapy..$^{7280}$

Aneuploidy is evident in $50-70 \%$ of patients with multiple myeloma, and preliminary evidence in relatively small numbers of patients suggests that ploidy is an independent prognostic variable: patients with diploid myelomas survive significantly longer than those with aneuploid myelomas. ${ }^{81-83}$ The relation between ploidy and response to treatment is not clear, and the improved survival of patients with diploid tumours may relate to their relative biological indolence rather than to their inherent chemosensitivity.

There are numerous problems with the morphological diagnosis of lymphomas, and it has been proposed that the flow cytometric analysis of cellular DNA content may be a useful adjunct to their clinicopathological assessment, particularly in the case of the non-Hodgkin's lymphomas. ${ }^{1984}$ There is an incidence of aneuploidy of up to $90 \%$ in the high grade lymphomas, while low grade lymphomas are more commonly diploid. A number of prospective studies are presently investigating the relation between ploidy and prognosis in the non-Hodgkin's lymphomas. ${ }^{19758485}$ Aneuploidy is evident in $70 \%$ of patients with mycosis fungoides and Sézary syndrome and is associated with the presence of adverse clinical features and a poor prognosis. ${ }^{45}$ Patients with aneuploid tumours are more likely to have advanced disease and early relapse, while patients with diploid tumours have a more indolent clinical course and significantly prolonged survival.

\section{SOLID TUMOURS}

\section{Breast cancer}

The ploidy of large numbers of breast tumours has been determined with static cytometry, flow cytometry, and chromosome analysis. All techni- ques have shown that there is a non-random distribution of ploidy with most tumours having either a near diploid or triploid-tetraploid mode, while a few have two distinct aneuploid populations (multiploidy) ${ }^{80-90}$ The general stability of cellular DNA content within different regions of a primary tumour and its metastases, regardless of location or time of occurrence, ${ }^{6061}$ supports the hypothesis that breast cancer has a monoclonal origin. This finding is also of practical importance as a single estimation of ploidy is likely to be representative of the tumour as a whole. There have been no consistent chromosomal abnormalities described in breast cancer, apart from frequent changes in chromosome $1 .^{8}$ Chromosome 1 is, however, the largest human chromosome and has a distinctive banding pattern so that changes in its structure can easily be observed, which probably accounts for why it is reported abnormal in so many human cancers. ${ }^{91}$

Depending on the technique used, aneuploidy has been reported in $50-80 \%$ of breast tumours and appears to be independent of tumour stage, size and nodal status. ${ }^{86-8892}$ An association between tumour ploidy and steroid receptor status has been shown, with near diploid tumours tending to be oestrogen receptor positive, but in most studies this has not achieved statistical significance. ${ }^{878892-95}$ It has been suggested that DNA measurements could be of value in predicting the sensitivity of breast tumours to endocrine treatment. ${ }^{93}{ }^{95}$ There is some evidence to support this hypothesis in prostate cancer, ${ }^{96} 97$ but not as yet in breast cancer. It has been postulated that the prevalence of multiploidy between the ages of 40 and 60 is a possible reason for the well known refractoriness of recurrent breast cancer to endocrine treatment in perimenopausal women, as the probability of these tumours containing a hormonally insensitive subclone may be high. ${ }^{88}$

An association between tumour ploidy and differentiation has been described, with well differentiated tumours tending to be diploid and poorly differentiated tumours aneuploid ${ }^{87}{ }^{98}$ It is possible that tumour ploidy may be an alternative to the currently used nuclear grading systems because it is objective and reproducible.

Benign breast tumours have a diploid DNA content, ${ }^{87} 92$ but tumour ploidy cannot be used as an absolute criterion to distinguish between benign and malignant tumours as the latter may also be diploid. The finding, however, of aneuploidy in so called benign breast tumours has been reported in a small number of patients who later developed invasive breast cancer ${ }^{99^{100}}$ and the value of DNA estimations in potentially premalignant breast lesions should be further studied.

There is evidence using static cytometry to show that cellular DNA content reflects the biology of 
breast cancer and is of prognostic importance. Atkin showed that patients with near diploid tumours had significantly better eight year survival rates than those with high ploidy tumours. ${ }^{89}$ Auer recently confirmed these results, showing a significant correlation between DNA content and survival in patients with stage I and II breast cancer ${ }^{86} \mathrm{His}$ data, analysed by subclassifying the DNA patterns of breast tumours into four groups, showed that patients with diploid or tetraploid tumours had a significantly better long term survival than patients with either aneuploid tumours or tumours with a high proliferative fraction. In both these studies it was suggested that ploidy was an independent prognostic variable and unrelated to clinical stage or axillary nodal status.

There are no published flow cytometric studies with sufficient follow up to confirm these results. Using a recently developed flow cytometric method which can be applied to archival, paraffin embedded tissue $^{69}$ we have examined 151 primary tumours from patients with stage II-that is, axillary lymph nodes positive-breast cancer who were entered into the Ludwig Institute for Cancer Research I-IV adjuvant breast trials. Preliminary analysis shows an improved prognosis for the patients with diploid tumours, since their disease free survival curve appears to plateau at two years, whereas patients with aneuploid tumours have the continuing risk of relapse characteristic of breast cancer. ${ }^{101}$ If this two year plateau is real it implies that the diploid tumours are either less aggressive or more responsive to adjuvant therapy, and this important question should be resolved when the target accrual of several hundred paraffin blocks have been examined.

It appears that cellular DNA content will be a valuable adjunct in the assessment of the biology of breast cancer. Long term follow up of a number of studies is awaited, but the association of diploid/near diploid tumours with other recognised prognostic variables such as tumour grade, oestrogen receptor expression, and proliferative fraction provides circumstantial evidence of their relative biological indolence.

\section{FEMALE GENITAL TRACT}

Ovary

A number of prognostic variables have been recognised in ovarian cancer. ${ }^{102}$ Their relative importance, however, particularly in advanced disease, has not been well clarified, and treatment decisions are usually made on the basis of stage alone. ${ }^{103}$

Recently, a consistent translocation between chromosome 6 and 14 has been reported in serous papillary cystadenocarcinoma of the ovary. ${ }^{104}$ Marker chromosomes have also been found in over
$70 \%$ of tumours and structural rearrangements have been shown in chromosomes $1,3,4,6,9,10,15$, and 19 , with chromosome 1 being abnormal in up to $40 \%$ of ovarian tumours ${ }^{8}{ }^{105}$ (for review see reference 106). The significance of these chromosomal abnormalities remains uncertain.

In contrast, there is evidence that the cellular DNA content reflects the biology of ovarian epithelial tumours and provides clinically relevant information. ${ }^{107-111}$ There is a bimodal distribution of ploidy with a clustering of tumours about a diploid or triploid-tetraploid mode, ${ }^{108}$ while about $15 \%$ of tumours are multiploidal. ${ }^{109110}$ As in breast cancer, ploidy is in most cases a stable marker in ovarian cancer exhibiting consistency within different sites of the primary tumour and metastases and during subsequent tumour progression. ${ }^{62}$ There is an important association between stage and tumour ploidy, with early stage tumours tending to be diploid while more advanced tumours are usually aneuploid. ${ }^{108} 109$

In a recent study of 91 patients with advanced ovarian cancer ploidy was determined by flow cytometric analysis of paraffin embedded tumour blocks: $69 \%$ of tumours were aneuploid and $31 \%$ were diploid. ${ }^{110}$ Patients with diploid tumours (mean survival $=123$ weeks) had a significantly longer survival than those with aneuploid or multiploid tumours (median survival 52 and 63 weeks, respectively), and multivariate analysis showed that tumour ploidy was the major determinant of survival ( $p<0.0001)$. Preliminary data suggest that this also holds true in early stage ovarian cancer, ${ }^{112}$ where the ability to predict patient outcome accurately could have important therapeutic implications. Studies are underway to determine whether this influence of ploidy on prognosis is a reflection of natural history or response to treatment.

Tumour grade is believed to be an important prognostic variable, particularly in early stage ovarian cancer, ${ }^{102}$ but there are conflicting views regarding its relation to tumour ploidy. ${ }^{108} 109113$ This probably reflects the inherent problems in the subjective grading of ovarian tumours, and an objective grading system based on DNA content may be more appropriate.

Borderline ovarian tumours (tumours of low malignant potential) account for $15 \%$ of ovarian tumours and as a group are characterised by an indolent biological behaviour even when spread beyond the ovaries occurs. ${ }^{114}$ Most long term survivors with advanced stage ovarian cancer have been shown to have had borderline tumours, ${ }^{115}$ and the correct diagnosis therefore has important prognostic and therapeutic implications. The diagnosis can, however, be difficult even for the experienced gynaecological pathologist, and there is evidence 
that the determination of cellular DNA content may be a useful adjunct to the histopathological diagnosis of borderline malignancy. Most borderline tumours are diploid, and the finding of aneuploidy could imply an aggressive biological behaviour. ${ }^{111} 116$

\section{UTERINE CERVIX}

As with ovarian cancer, stage is generally accepted to be the most important prognostic factor in cervical cancer. ${ }^{17}$ Only a few attempts have been made to study cervical cancers with banding techniques and to date no consistent chromosomal abnormality has emerged. ${ }^{118}$ Using static cytometry, Atkin reported a worse prognosis for the near diploid group in patients with squamous cell carcinoma of the cervix, ${ }^{108119120}$ but these findings were not significant on application of multiple regression analysis and have not been confirmed. The results of a flow cytometric study by Jakobson involving 171 patients with squamous cell carcinoma of the cervix showed that patients with low ploidy tumours (DNA index $<1 \cdot 5$ ) had a significantly better prognosis than those with high ploidy (DNA index >1.5) tumours. ${ }^{121}$ The distribution of ploidy was not correlated with stage, and there was a significantly higher recurrence frequency in patients with high ploidy tumours in all stages investigated. As it is particularly difficult to determine response to radiotherapy, it was not clear if the difference in recurrence rate and overall survival in this study was due to an increased radiosensitivity of low ploidy tumours.

There is a significant correlation between DNA index and the incidence of pelvic lymph node metastases in patients with stage IB and IIA tumours, with high ploidy tumours having a higher likelihood of metastasising. ${ }^{122}$ This finding could have important implications in terms of the choice of treatment and deserves further study in larger numbers of patients.

In a study of intraepithelial neoplasms Jakobson has shown that flow cytometry may be a useful adjunct to histopathological classification since cells exhibiting mild to moderate dysplasia were invariably diploid while areas of severe dysplasia and carcinoma in situ were usually aneuploid, with a frequency approaching that of invasive cervical cancer. ${ }^{123}$ These findings are in accordance with cytogenetic investigations, which showed only $29 \%$ of cases of carcinoma in situ had a chromosome number in the diploid range. ${ }^{124}$ The presence of aneuploidy indicates an increased likelihood of progression to invasive cancer and it has been suggested that lesions with an aneuploid pattern should be considered to be precursors of invasive cervical cancer. ${ }^{125}$

The prognosis of adenocarcinoma of the cervix is related predominantly to clinical stage and to a lesser extent to histological type, growth pattern, and degree of differentiation. ${ }^{126}$ Early stage tumours and better differentiated tumours tend to be of low ploidy, but even within tumours of a similar stage and differentiation, low ploidy tumours have a considerably better prognosis than high ploidy tumours. ${ }^{127}$ Similar studies of clear cell carcinoma of cervix and vagina have also shown that clinical stage is the over-riding prognostic factor, and although the results in a small group of patients with clinically low stage tumours suggested that the prognosis was slightly better if ploidy level was low rather than high, the finding was not statistically significant. ${ }^{128}$

\section{ENDOMETRIAL CANCER}

There have been few studies of chromosomes or cellular DNA content in endometrial cancer, but the data that are available show that near diploid tumours have a considerably better prognosis that those with high ploidy. ${ }^{19}$ Most endometrial tumours are near diploid, and although the ratio of well differentiated to poorly differentiated tumours is greater in the near diploid group, the difference in prognosis cannot be solely related to the degree of differentiation. ${ }^{119} 129$

\section{PROSTATE}

A characteristic feature of prostatic cancer is the great variation in biological behaviour, ranging from latent carcinoma to highly aggressive metastasising carcinoma; this wide clinical range is only partly reflected in the morphological features. ${ }^{130}$ Detailed chromosome analyses of human prostatic cancer, either primary or metastatic, are lacking. ${ }^{8}$ Retrospective studies using static cytometry have shown that diploid tumours have a considerably better prognosis than aneuploid tumours ${ }^{96131}$ and that diploid tumours also have a higher response probability to oestrogen treatment, which may explain their different biological behaviour. ${ }^{9697}$

The DNA content of prostatic tumours can now be estimated using fine needle aspirates, which provide material well suited to flow cytometry ${ }^{132}{ }^{133}$; a number of prospective studies are underway. Although well differentiated tumours tend to be diploid and poorly differentiated tumours tend to be aneuploid, about half of the moderately differentiated tumours are diploid and half aneuploid. ${ }^{133134}$ This finding is of particular interest since moderately differentiated tumours are common, and are clinically recognised to be heterogeneous with regard to survival and response to treatment.

Tetraploid populations are common in prostatic carcinomas, but the clinical importance is unknown, as polyploidisation may be a normal feature in certain tissues. ${ }^{133}$ The presence of multiploidy has been thought to be evidence of tumour aggressiveness, and this is supported partly by the finding that $22 \%$ 
of poorly differentiated tumours have evidence of multiple cell lines while no well differentiated tumours exhibit multiploidy. ${ }^{134}$

\section{BLADDER CANCER}

Clinical and morphological parameters alone are not sufficient to assess the possible outcome of patients with bladder tumours. ${ }^{135}$ Attempts to identify new and objective prognostic variables have led to a number of studies of chromosomal analysis and cellular DNA content. The results of the first comprehensive study of chromosomes in bladder cancer, which appeared in 1967 , indicated a relation between chromosome number, histological appearance, and invasiveness of the tumour. ${ }^{136}$ Non-invasive tumours had a near diploid mode, while poorly differentiated tumours tended to have a modal chromosome number in the triploid-tetraploid range. These findings have been confirmed by other studies, which have also indicated that marker chromosomes have potential prognostic value and their presence in papillary tumours is associated with high likelihood of recurrence. ${ }^{137} 138$

Similar findings have been reported with quantitative DNA analysis using static cytometry. Tumour ploidy has been shown to correlate well with biological behaviour, patients with diploid tumours having a survival advantage..$^{96139}$ A number of large prospective flow cytometric studies are currently underway, and interim findings relating ploidy to tumour grade, stage, and recurrence rate have been reported. ${ }^{135}$ 140-142 Grade 2 (moderately differentiated) tumours constitute a heterogeneous group with respect to survival and are also heterogeneous with respect to DNA content. About $66 \%$ of grade 2 tumours are diploid and $34 \%$ are aneuploid, while grade 1 tumours are usually all diploid and grade 3 tumours invariably aneuploid. ${ }^{135}$ The DNA pattern, histological grade, and recurrence rate have been studied in superficial bladder tumours. ${ }^{141} 142$ Progression occurred in tumours with a triploid DNA content, rarely in tetraploid tumours, and not at all in diploid tumours. These results show that superficial bladder tumours can be well characterised by their DNA profiles. There is a significant association with tumour ploidy and stage (TNM classification), with about $60 \%$ of $T_{1}$ tumours being diploid while $T_{2}-T_{4}$ tumours are usually aneuploid and are more likely to contain multiple aneuploid cell lines. ${ }^{135}$ In a small study of 20 patients with in situ primary carcinoma of the urinary bladder aneuploidy was found in all cases. In seven of these more than one aneuploid cell line was evident and in all these cases progression occurred within two years. ${ }^{140}$

Bladder tumours are often multifocal in origin and can have different histological appearances in different areas. ${ }^{143}$ The incidence of intratumoral var- iations of ploidy and the possible variations in different sites have not, however, been widely studied. ${ }^{144}$

As the clinical management of transitional cell tumours of the urinary bladder is strongly dependent on the correct histopathological grading, which is associated with both inter- and intraindividual discrepancies, ${ }^{145} 146$ it is likely that determination of cellular DNA content will find a place as an adjunct to the histopathological assessment of bladder cancer.

\section{RENAL CANCER}

In renal cancer ploidy is in most cases a stable tumour marker, with little variation occurring within different sites of the primary tumour. It has been estimated that by taking two samples from different regions the probability of missing a hyperdiploid population is less than $1 \% .^{63}$ Cell populations with an aneuploid DNA content were detected in $46 \%$ of renal carcinomas, and the comparison of ploidy with histological grade showed that most highly malignant grades are aneuploid while $45 \%$ of the hyperdiploid and $89 \%$ of diploid tumours are of a low grade. These initial results indicate that aneuploidy might provide useful prognostic information, as after follow up of six months to two years, $47 \%$ of patients with hyperdiploid tumours and only $9 \%$ of patients with diploid tumours died or developed multiple metastases. ${ }^{63}$ As the tumour ploidy is not strictly correlated with nuclear morphology it has been suggested that prognosis might be determined more accurately using a grading system based on both ploidy and histological grade..$^{147} 148$

\section{LUNG}

Aneuploidy is common in epidermoid carcinoma, adenocarcinoma, and small cell lung cancer, and a typical bimodal distribution is common to all; ploidy levels tend to be higher in epidermoid cancer than in adenocarcinomas. ${ }^{65} 149-151$ A relatively high incidence of clonal heterogeneity has been reported in small cell lung cancer, with up to $30 \%$ of tumours having evidence of two aneuploid clones. ${ }^{65}$ Unlike breast cancer and ovarian cancer, there are commonly differences in ploidy between the primary tumour and metastases. This "genetic instability" or clonal heterogeneity may account for the rapid emergence of drug resistance in a tumour type which is characterised by high response rates to chemotherapy but a low percentage of long term survivors. ${ }^{65}$ The finding of a stable hypodiploid/near diploid clone in small cell lung cancer is associated with a better prognosis, but as these patients also tend to have limited disease the value of ploidy as an independent prognostic variable has not been shown. ${ }^{150}$ The reason for the improved prognosis may reflect drug response: unimodal hypodiploid/ 
diploid small cell lung cancers have been reported to have a longer duration of response and better survival than patients with hyperdiploid tumours. ${ }^{152}$ Although there are few chromosomal studies reported in lung cancers, the data that are available also suggest that hypodiploidy is a feature of some small cell lung cancers. A specific chromosomal finding (3p-) has also been noted in small cell lung cancer but its importance is unclear. ${ }^{153}$

The assessment of tumour ploidy as an adjunct to the histopathological distinction of carcinoid tumours from small cell lung cancer may be useful as carcinoid tumours are almost invariably diploid and have an indolent behaviour. ${ }^{150}$

Epidermoid carcinomas and adenocarcinomas of the lung have been reported to have a better prognosis if they exhibit a near diploid DNA content. ${ }^{154}$ iss But this is an area where larger numbers of patients should be studied to determine whether ploidy is an independent prognostic variable.

\section{COLONIC CANCER}

The behaviour of colonic cancer is predicted mainly on the basis of clinico-pathological staging and histological grading. ${ }^{156}$ Recent studies based on a relatively small number of patients have suggested that the determination of DNA distribution in colon carcinomas may be of prognostic value. ${ }^{157} 158$ Patients with diploid tumours have a considerably better prognosis than those with aneuploid tumours, independent of histological grade and Dukes' stage. ${ }^{158}$ Other biological differences between diploid and aneuploid colonic carcinomas have also been shown: the production of carcinoembryonic antigen is more common in aneuploid tumours while the release of the secretory component of $\operatorname{IgA}$ is more common in diploid tumours. ${ }^{159}$ Colonic carcinomas are commonly heterogeneous with respect to DNA content, with up to $30 \%$ of tumours showing regional variations in ploidy independent of histological differentiation $^{64}$; the biological importance of this is not

\section{MELANOMA}

There are few data available relating ploidy and survival in melanoma. Aneuploidy has been reported to be present in $70-90 \%$ of malignant melanomas, with up to $30 \%$ of cases having multiple aneuploid cell populations. ${ }^{57160}$ A considerable variation in chromosome numbers has similarly been found between cells within the same tumours. ${ }^{161}$ There is a significant correlation between aneuploidy and melanoma thickness, but no such correlation with level of invasion or histological type.$^{160}$ In one study of patients with localised and regional disease more patients with aneuploid tumours died than those with diploid tumours, and multiploidy was associated with a particularly high mortality. These findings did not achieve statistical significance, however, possibly because of the small numbers of patients in the study. ${ }^{160}$

\section{BRAIN TUMOURS}

DNA distribution has been studied in both malignant and benign brain tumours, but its biological importance remains unclear. ${ }^{66} 162-166$ There is some evidence that DNA content is not a stable marker and may vary within different regions of a tumour and change on recurrence ${ }^{66}$ It is tempting to speculate that the relatively common occurrence of heterogeneity of tumour ploidy within brain tumours, colonic cancer, small cell lung cancer, and melanomas reflects their biological behaviour, which is usually characterised by either intrinsic chemoresistance or by the rapid emergence of drug resistance. There are conflicting results with respect to the relation of ploidy to grade, and while diploid modal values are evident in most benign brain tumours it has been reported that poorly differentiated gliomas may also have a diploid or near diploid DNA mode. ${ }^{162} 165$ Aneuploidy is common in malignant brain tumours, but no obvious correlation between DNA pattern and prognosis has been found. ${ }^{164}$ This finding may reflect the fact that small numbers of patients with a wide variety of brain tumours have been analysed together, and in many instances the techniques used had a low resolution in discriminating diploid tumours from aneuploid tumours.

Meningiomas are usually considered to be histologically benign and in most instances have a diploid DNA content. ${ }^{163166}$ Chromosomal analysis and banding has been performed in a large number of meningiomas, and monosomy 22 is reported to be a frequent and specific finding, although the clinical importance of this is unclear. ${ }^{167}$

\section{BONE TUMOURS}

A number of studies using absorption cytophotometry to determine cellular DNA content of both osteosarcomas and chondrosarcomas have shown that tumour ploidy reflects the biological behaviour of bone tumours. ${ }^{168} 169$ In a retrospective study of 45 patients with chondrosarcomas, patients with diploid tumours had a significantly better prognosis than patients with aneuploid tumours regardless of location, size of tumour, histological grade, or treatment. ${ }^{169}$ Of patients with diploid tumours $81 \%$ survived 10 years, compared with $29 \%$ of the patients with aneuploid tumours, and it seems that ploidy determinations may complement conventional histopathological and clinical assessment of the biological behaviour of chondrosarcomas.

The histological diagnosis of osteosarcoma may sometimes present considerable difficulties, and the distinction between high grade osteosarcomas from 
Prognostic significance of cellular DNA content in human cancer

\begin{tabular}{|c|c|c|c|c|c|c|}
\hline \multirow[t]{2}{*}{ Tumour type } & \multirow{2}{*}{$\begin{array}{l}\text { Survival } \\
\text { advantage } \\
\text { for diploid } \\
\text { tumours }\end{array}$} & \multirow[t]{2}{*}{ Stage } & \multicolumn{2}{|c|}{ Ploidy correlates } & \multirow[t]{2}{*}{ Other } & \multirow[t]{2}{*}{ References } \\
\hline & & & $\begin{array}{l}\text { Histological } \\
\text { subtype }\end{array}$ & $\begin{array}{l}\text { Histological } \\
\text { grade }\end{array}$ & & \\
\hline \multicolumn{7}{|l|}{ Solid tumours } \\
\hline Breast & + & - & + & + & Receptor expression & $86-89,92-95,101$ \\
\hline Ovary* & + & + & - & \pm & Borderline malignancy & $107-111,113,116$ \\
\hline Cervix $\dagger$ & + & - & - & - & Lymph node spread & $121-123,127$ \\
\hline Endometrium & + & - & - & + & & 119,129 \\
\hline Prostate & + & - & - & + & Hormone responsiveness & $96,97,131-135$ \\
\hline Bladder & + & + & - & + & & $96,139-142$ \\
\hline Renal§ & + & - & - & + & & $63,147,148$ \\
\hline Lung§ & + & + & - & - & & $149-152,154,155$ \\
\hline Colon§ & + & - & - & - & Carcinoembryonic & \\
\hline & & & & & antigen production & $156-159$ \\
\hline Melanoma§ & - & - & - & - & & 57,160 \\
\hline Brain§ & - & - & - & - & & $66,162-166$ \\
\hline Bone & + & + & + & + & & 168,169 \\
\hline \multirow{2}{*}{\multicolumn{7}{|c|}{ Haematological }} \\
\hline & & & & & & \\
\hline leukaemiał & - & & & & Immunological phenotype & $76-78$ \\
\hline Acute myelocytic & & & & & & \\
\hline leukaemia & + & & & & & 72,80 \\
\hline Myeloma* & + & + & - & - & & 81,83 \\
\hline Mycosis fungoides & + & + & & & & \\
\hline Sezary's syndrome & & & & & & \\
\hline Lymphomas & \pm & & + & + & & $19,75,84,85$ \\
\hline
\end{tabular}

*Ploidy shown to be an independent prognostic variable by multivariate analysis.

tConflicting data-early study showed aneuploid tumours to have a better prognosis (although not significant). ${ }^{118}$

$\ddagger$ Patients with aneuploid tumours have significantly better survival than those with diploid tumours.

Intratumoral heterogeneity of ploidy relatively common.

Follow up too short for definite conclusions.

$+=$ positive correlation.

$-=$ no correlation.

low grade indolent parosteal variants can be difficult. ${ }^{170}$ The analysis of tumour ploidy may be valuable in this setting, as has been shown in a small study where parosteal variants were diploid and classic osteosarcomas were aneuploid. ${ }^{168}$

\section{PHEOCHROMOCYTOMAS}

Malignant pheochromocytomas are rare tumours which are difficult to diagnose, and it has been claimed that the only absolute criterion for diagnosis is the presence of secondary deposits. ${ }^{171}$ Benign pheochromocytomas have a diploid DNA content ${ }^{172}$ while malignant tumours have an aneuploid DNA content, and it is likely that determination of cellular DNA content will enable the biological behaviour of this rare group of tumours to be determined.

\section{CONCLUSIONS}

The cytogenetic analysis of solid tumours has until recently found little practical application, and clinical and histological criteria have largely been relied on to assess the biological properties of a tumour and to predict the patient's outcome. It has been suggested for many years that both chromosomal analysis and quantitative DNA estimation may have a role in evaluating tumour behaviour and prognosis, but technical factors precluded them from widespread use. While the chromosomal analysis and banding of solid tumours is still essentially confined to basic cancer research, recent technological advances have made quantitative DNA analysis and estimation of tumour ploidy relatively simple, rapid, and well suited for clinical application.

The flow cytometric analysis of DNA content appears to provide an objective assessment of the inherent malignant potential in a large number of tumour types (Table). There are, however, inadequacies in some of the reported studies as the relation between ploidy and other prognostically important features such as stage and grade are not always mentioned. In addition, the effect of tumour ploidy on response to treatment needs further elucidation. If the studies suggesting a correlation between response probability and tumour ploidy are confirmed the applications will be wide, as it is not usually possible to predict the likelihood of a long term response to chemotherapy.

The fundamental reasons behind variability in the biological behaviour of histologically similar tumours with different DNA contents still needs to be explained. Causative factors may be important as it has been shown that different aetiological agents can cause histologically identical animal tumours with different, yet consistent, karyotypic patterns. ${ }^{173}$ Alternatively, quantitative differences in gene dosage or mutation rate may also account for the behaviour of certain tumours. ${ }^{174}$ It is likely that with 
the rapid inroads being made in the field of molecular biology and cytogenetics explanations for the clinical importance of aneuploidy will be forthcoming.

We wish to express our appreciation to Judy Hood for typing this manuscript, to Cathy Rugg and Liz Musgrove for excellent technical assistance, and to Dr Peter Russell and Professor Alan Ng for providing tumour specimens and for their histopathological expertise and advice. We are grateful to Professor Martin Tattersall for his continued support and encouragement and for his critical appraisal of this manuscript.

\section{References}

' Rowley JD. Chromosome abnormalities in cancer. Cancer Genetics and Cytogenetics 1980;2:175-198.

${ }^{2}$ Krontiris TG. The emerging genetics of human cancer. $N$ Engl $J$ Med 1983; 309:404-9.

${ }^{3}$ Tabin CJ, Bradley SM, Bargmann CI, et al. Mechanism of activation of a human oncogene. Nature 1982;300:143-9.

${ }^{4}$ Oncogenes in solid tumours. Nature 1982;300:477.

5 Pulciani S, Santos E, Lauver AV, Long LK, Aaronson SA, Barbacid M. Oncogenes in solid tumours. Nature 1982;300:53942.

- Rechavi G, Givol D, Canaani E. Activation of a cellular oncogene by DNA rearrangement: possible involvement of an IS-like element. Nature 1982;300:607-11.

${ }^{7}$ Cairns J. The origin of human cancers. Nature 1981;289:353-7.

${ }^{8}$ Sandberg AA. The chromosomes in human cancer and leukemia. New York: Elsevier, North Holland, 1980.

' Owerbach D, Rutter WJ, Martial JA, Baxter JD, Shows TB. Genes for growth hormone, chorionic somatomammotropin and growth hormone-like gene on chromosome 17 in humans. Science 1980;209:289-92.

${ }^{10}$ Owerbach D, Bell GI, Rutter WJ, Shows TB. The insulin gene is located on chromosome 11 in humans. Nature 1980; 286:82-4.

"Mitelman F, Levan G. Clustering of aberrations to specific chromosomes in human neoplasms II. A survey of 287 neoplasms. Hereditas 1976;82:167-74.

${ }^{12}$ Sachs L. Control of normal cell differentiation and phenotypic reversion of malignancy in myeloid leukemia. Nature 1978;274:535-9.

${ }^{13}$ George DL, Francke U. Gene dose effect: regional mapping of human nucleoside phosphorylase on chromosome 14. Science 1976; 194:851-2.

${ }^{14}$ Cifone M, Fidler IJ. Increasing metastatic potential is associated with increasing genetic instability of clones isolated from murine neoplasms. Proc Natl Acad Sci USA 1981;78:694952.

${ }^{15}$ Ohno S. Genetic implication of karyological instability of malignant somatic cells. Physiol Rev 1971;51:496-526.

${ }^{16}$ Nowell PC. The clonal evolution of tumour cell populations. Science 1976; 194:23-8.

${ }^{17}$ First International Workshop on Chromosomes in Leukemia. Chromosomes in acute non-lymphocytic leukemia. $\mathrm{Br} J$ Haematol 1978;39:311-6.

${ }^{18}$ Second International Workshop on Chromosomes in Leukemia. Cancer Genetics and Cytogenetics 1980;2:89-113.

${ }^{19}$ Diamond LW, Nathwani BN, Rappaport H. Flow cytometry in the diagnosis and classification of malignant lymphoma and leukemia. Cancer 1982;50:1122-35.

${ }^{20}$ Kaneko Y, Rowley JD, Variakojis D, Chilcote RR, Check I, Sakurai M. Correlation of karyotype with clinical features in acute lymphoblastic leukemia. Cancer Res 1982;49:2918-29.

${ }^{21}$ Rowley JD. Chromosomes in leukemia and lymphoma. Semin Hematol 1978;15:301-19.

${ }^{22}$ Nowell PC, Hungerford DA. A minute chromosome in human granulocytic leukemia. Science 1960;132:1497.

${ }^{23}$ Whang-Peng J, Canellos GP, Carbone PP, Tijo HH. Clinical implications of cytogenetic variants in chronic myelocytic leukemia (CML). Blood 1968;32:755-66.

${ }^{24}$ Hecht F, McCaw BK. Chromosome instability syndromes. In: Mulhill JJ, Miller RW, Fraumeni JF, eds. Progress in cancer research and therapy. Vol 3. New York: Raven Press, 1977;105-23.

${ }^{25}$ German J. Genes which increase chromosomal instability in somatic cells and predispose to cancer. Prog Med Genet 1972;8:61-101.

${ }^{26}$ Dalla-Favera R, Bregni M, Erikson J, Patterson D, Gallo RC, Croce CM. Human c-myc onc gene is located on the region of chromosome 8 that is translocated in Burkitt lymphoma cells. Proc Natl Actl Sci USA 1982;79:7824-7.

${ }^{27}$ Harden DG, Taylor AMR. Chromosomes and neoplasia. In: Harris H, Kirschhhorn K, eds. Advances in human genetics. London: Plenum Press, 1979;1-69.

28 Carrano AV, Gray JW, Van Dilla MA. Flow cytogenetics: progress towards chromosomal aberration detection. In: Evan $\mathbf{H J}$, Lloyd DC, eds. Mutagen induced chromosome damage in man. Edinburgh: Edinburgh University Press, 1978;326-38.

${ }^{24}$ Melamed MR, Mullaney PR, Mendelsohn ML. Flow cytometry and sorting. New York: John Wiley, 1979.

${ }^{30}$ Bohm N, Sandritter W. DNA in human tumours: A cytophotometric study. Curr Top Pathol 1975;60:152-219.

${ }^{31}$ Laerum OD, Farsund T. Clinical application of flow cytometry: A review. Cytometry 1981;2:1-13.

${ }^{32}$ Wied GL, ed. Introduction to quantitative cytochemistry. London: Academic Press, 1966.

${ }^{33}$ Wied GL, Bahr GF. Introduction to quantitative cytochemistry II. London: Academic Press, 1970.

${ }^{34}$ Tjio JH, Whang J. Direct chromosome preparations of bone marrow cells. In: Yunis JJ, ed. Human chromosome methodology. London: Academic Press, 1974;51-6.

${ }^{35}$ Harden DG. Skin culture and solid tumour technique. In: Yunis JJ, ed. Human chromosome methodology. 2nd ed. London: Academic Press, 1974;167-84.

${ }^{36}$ Caspersson T, Zech L, Johanssen C. Differential binding of alkylating fluorochromes in human chromosomes. Exp Cell Res 1970;60:315-9.

${ }^{37}$ Verma RS, Dosik H. Recent advances in detecting human chromosomal abnormalities by various banding techniques. Pathol Ann 1982:17:261-86.

${ }^{38} \mathrm{Tjio} \mathrm{JH}$, Levan A. The chromosome number of man. Hereditas 1956;42: 1 .

${ }^{34}$ Sandberg AA. Chromosomal changes in human cancers: specificity and heterogeneity. In: Owens AH, Coffey DS, Baylin SB, eds. Tumour cell heterogeneity: origins and implications. New York: Bristol Myers Cancer Symposia, 1982;4:367-97.

${ }^{40}$ Brodsky WY, Uryvaeva IV. Cell polyploidy: its relation to tissue growth and function. Int Rev Cytol 1978;50:275-332.

${ }^{41}$ Cowell JK, Wigley CB. Changes in DNA content during in vitro transformation of mouse salivary gland epithelium. J Natl Cancer Inst 1980;64:1443-8.

${ }^{42}$ Kraemer PM, Petersen DF, Van Dilla MA. DNA constancy in heteroploidy and the stem line theory of tumours. Science 1971; 174:714-7.

${ }^{43}$ Jakobsen $A$, Nielsen KV, Ronne $M$. DNA distribution and chromosome number in human cervical carcinoma. Analytical and Quantitative Cytology 1983;5:13-8.

${ }^{44}$ Bosman FT, Groen FCA, Van der Ploeg M. DNA content and chromosome number of a heteroploid cell line. Histochemistry 1979; 60: $181-8$.

${ }^{45}$ Bunn PA, Whang-Peng J, Carney DN, Schlam ML, Knutsen T, 
Gazdar AF. DNA content analysis by flow cytometry and cytogenetic analysis in mycosis fungoides and Sezary syndrome. Diagnostic and prognostic implications. J Clin Invest 1980;65:1440-8.

${ }^{46}$ Atkin NB. Modal DNA value and chromosome number in ovarian neoplasia. A clinical and histopathologic assessment. Cancer 1970;27:1064-73.

${ }^{47}$ Diamond LW, Bearman RM, Berry PK, et al. Prolymphocytic leukemia: Flow microfluorimetric, immunologic and cytogenetic observations. Am J Hematol 1980;9:319-30.

${ }^{48}$ Pearse AGE, ed. Histochemistry: theoretical and applied. 3rd ed. Vol 1. Boston: Little, Brown and Co, 1968;254-67.

${ }^{49}$ Deitch AD. Cytophotometry of nucleic acids. In: Wied GL, ed. Introduction to quantitative cytochemistry. Vol 1. New York: Academic Press, 1966;327-54.

${ }^{\text {so }}$ Caspersson TO. Quantitative tumour cytochemistry. In: Clowes GHA, ed. Memorial Lecture. Cancer Res 1979;39:2341-55.

si Taylor IW. A rapid single step staining technique for DNA analysis by flow microfluorimetry. J Histochem Cytochem 1980;28: $1021-4$

52 Taylor IW, Milthorpe BK. An evaluation of DNA fluorochromes staining techniques, and analysis for flow cytometry I. Unperturbed cell populations. J Histochem Cytochem 1980;28:1224-32.

${ }^{53}$ Shackney SE, Erikson BW, Skramstad KS. The T lymphocyte as a diploid reference standard for flow cytometry. Cancer Res 1979;39:4418-22.

s4 Jakobsen A. The use of trout erythrocytes and human lymphocytes for standardization in flow cytometry. Cytometry 1983;4:161-6.

${ }^{5 s}$ Barlogie B, Drewinko B, Schumann J, et al. Cellular DNA Content as a marker of neoplasia in man. Am J Med 1980;69: 195-203.

so Perez DJ, Taylor IW, Milthorpe BK, McGovern VJ, Tattersall MHN. Identification and quantitation of tumour cells in cell suspensions: A comparison of cytology and flow cytometry. $\mathrm{Br}$ J Cancer 1981;43:526-31.

57 Hannsson J, Tribukait B, Lewensohn R, Ringborg U. Flow cytofluorometric DNA analyses of metastases of human malignant melanomas. Analytical and Quantitative Cytology 1982;25:99-104.

${ }^{58}$ Barlogie B, Hittelman W, Spitzer G, et al. Correlation of DNA distribution abnormalities with cytogenetic findings in human adult leukemia and lymphoma. Cancer Res 1977;37:4400-7.

${ }^{59}$ Barlogie B, Johnston DA, Smallwood L, et al. Prognostic implications of ploidy and proliferative activity in human solid tumours. Cancer Genetics and Cytogenetics 1982;6:17-28.

${ }^{60}$ Auer GU, Arrhenius E, Granberg P, Fox CH. Comparison of DNA distributions in primary human breast cancers and their metastases. Eur J Cancer 1980;16:273-8.

${ }^{61}$ Meek ES. The cellular distribution of deoxyribonucleic acid in primary and secondary growths of human breast cancer. $J$ Pathology and Bacteriology 1962;82:167-72.

${ }^{02}$ Friedlander ML, Taylor IW, Russell P, Tattersall MHN. Cellular DNA content-a stable marker in epithelial ovarian cancer. Br J Cancer 1984;49:173-9.

${ }^{63}$ Baisch H, Otto U, Konig K, Kloppel G, Kollerman M, Linden WA. DNA content of human kidney carcinoma cells in relation to histological grading. Br J Cancer 1982;45:878-86.

${ }^{64}$ Petersen SE, Lorentzen M, Bichel P. A mosaic subpopulation structure of human colorectal carcinomas demonstrated by flow cytometry. In: Laerum OD, Lidmo T, Thorud E, eds. Flow cytometry IV. Oslo: Universitetsforlaget, 1980;412-6.

os Vindelov LL, Hansen HH, Christensen IJ, et al. Clonal heterogeneity of small cell anaplastic carcinoma of the lung demonstrated by flow cytometric DNA analysis. Cancer Res 1980;40:4295-300.

${ }^{66}$ Frederickson P, Bichel P. Sequential flow analysis of the single cell DNA content in recurrent human brain tumours. In: Laerum OD, Ludmo T, Thorud E, eds. Flow cytometry IV.
Oslo: Universitetsforlaget, 1980;398-402.

${ }^{67}$ Auer G, Tribukait B. Comparative single cell and flow DNA analysis in aspiration biopsies from breast carcinomas. Acta Pathol Microbiol Scand $[A]$ 1980;88:355-8.

${ }^{68}$ Fossa SD, Thorud E, Vaage S, Shoaib MC. DNA cytometry of primary breast cancer. Comparison of microspectrophotometry and flow cytometry, and different preparation methods for flow cytometric measurements. Acta Pathol Microbiol Scand $[A]$ 1983;91:235-43.

${ }^{69}$ Hedley DW, Friedlander ML, Taylor IW, Rugg CA, Musgrove EA. Method for analysis of cellular DNA content in paraffinembedded pathological material using flow cytometry. $J$ Histochem Cytochem 1983;31:1333-5.

${ }^{70}$ Garson OM. Cytogenetics of leukemic cells. In: Gunz FW, Henderson ES, eds. Leukemia. 4th ed. New York: Grune and Stratton, 1983;167-95.

"Garson OM. The value of chromosome studies in the classification and management of the leukemias. Pathology $1982 ; 14: 291-4$.

${ }^{72}$ Sakurai M, Sandberg AA. Prognosis of acute myeloblastic leukemia: Chromosomal correlation. Blood 1973;41:93-104.

${ }^{73}$ Bloomfield CD, Arthur DC, Frizzera G, Levine EG, Petersen BA, Gajl-Peczalska K. Non random chromosome abnormalities in lymphoma. Cancer Res 1983;43:2975-84.

${ }^{74}$ Andreef M, Darzynkiewics Z, Sharpless LJK, Clarkson BD, Melamed MR. Discrimination of human leukemia subtypes by flow cytometric analysis of cellular DNA and RNA. Blood 1980;55:282.

${ }^{75}$ Barlogie B, Latreille J, Freireich E, et al. Characterisation of haematologic malignancies by flow cytometry. Blood Cells 1980;6:719-44.

${ }^{76}$ Look AT, Melvin SL, Williams DL, et al. Aneuploidy and percentage of $S$ phase cells determined by flow cytometry correlate with cell phenotype in childhood acute leukemia. Blood 1982;60:959-67.

" Look AT, Melvin SL, Williams DL, et al. Clinical and biological implications of flow cytometric determination of aneuploidy and pretreatment $\% \mathrm{~S}$ phase of marrow blasts in childhood acute lymphoblastic leukemia. Seventh annual meeting of the Cell Kinetics Society, March 1983, G2:54.

${ }^{78}$ Wormann B, Hidemann W, Ritter J, et al. DNA aneuploidy in childhood ALL-incidence and relation to prognostic factors. Proceedings of the American Association of Cancer Research 1983; 637:161.

${ }^{74}$ Third international workshop on chromosomes in leukemia Cancer Genetics and Cytogenetics 1982;4:95-142.

${ }^{80}$ Barlogie B, Raber MN, Schumann J, et al. Flow cytometry in clinical cancer research. Cancer Res 1983;43:3982-97.

${ }^{81}$ Lewersohn R, Tribukait B, Hansson J. DNA content of human myeloma cells. Eur J Cancer Clin Oncol 1983; 19:59-63.

${ }^{82}$ Latreille J, Barlogie B, Dosik G, Johnston DA, Drewinko B, Alexanian R. Cellular DNA Content as a marker of multiple myeloma. Blood 1980;55:403-8.

${ }^{83}$ Bunn PA, Krasnow S, Makuch RW, Schlam ML, Schechter GP Flow cytometric analysis of DNA content of bone marrow cells in patients with plasma cell myeloma: clinical implications. Blood 1982;59:528-35.

${ }^{84}$ Diamond LW, Braylan RC. Flow analysis of DNA content and cell size in non-Hodgkin's lymphoma. Cancer Res 1980; 40: 703-12.

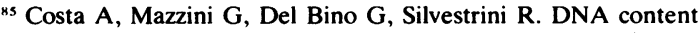
and kinetic characteristics of non Hodgkin's lymphoma: determined by flow cytometry and autoradiography. Cytometry 1981;2:185-8.

*s Auer GU, Caspersson TO, Wallgren AS. DNA content and survival in mammary carcinoma. Analytical and Quantitative Cytology 1980;2:161-5.

${ }^{87}$ Olszewski W, Darzynkiewicz Z, Rosen PP, Schwartz MK, Melamed MR. Flow cytometry of breast carcinoma. I. Relation of DNA ploidy level to histology and estrogen receptor. 
Cancer 1981;48:980-4.

${ }^{88}$ Taylor IW, Musgrove EA, Friedlander ML, Foo MS, Hedley DW. The influence of age on the DNA ploidy levels of breast tumours. Eur J Cancer Clin Oncol 1983;19:623-8.

${ }^{89}$ Atkin NB. Modal deoxyribonucleic acid value and survival in carcinoma of the breast. Br Med J 1972;i:271-2.

${ }^{90}$ Atkin NB. Chromosomes in human malignant tumours. In: German, ed. Chromosomes and cancer. New York: Wiley, $1974 ; 375-422$.

${ }^{91}$ Kovacs GY. Abnormalities of chromosome no 1 in human solid malignant tumours. Int J Cancer 1978;21:688-94.

${ }^{92}$ Kute TE, Muss HB, Anderson D, et al. Relationship of steroid receptor, cell kinetics and clinical status in patients with breast cancer. Cancer Res 1981;41:3524-9.

${ }^{43}$ Bichel P, Poulsen HS, Andersen J. Estrogen receptor content and ploidy of human mammary carcinoma. Cancer 1982; 50: $1771-4$

${ }^{4}$ Raber MN, Barlogie B, Latreille J, Bedrossian C, Fritsche H, Blumenschein G. Ploidy, proliferative activity and estrogen receptor content in human breast cancer. Cytometry 1982;3:36-41.

9s Auer G, Caspersson TO, Gustafsson SA, et al. Relationship between nuclear DNA distribution and estrogen receptors in human mammary carcinomas. Analytical and Quantitative Cytology 1980;2:280-4.

90 Tavares AS, Costa J, De Carvalho A, Reis M. Tumour ploidy and prognosis in carcinomas of the bladder and prostate. $\mathrm{Br} \mathbf{J}$ Cancer 1966;20:438-41.

${ }^{97}$ Zetterberg A, Esposti PL. Prognostic significance of nuclear DNA levels in prostatic carcinoma. Scand J Urol Nephrol 1980;55(suppl):53-9.

${ }^{98}$ Tavares AS. Ploidy and histological types of mammary carcinomas. Eur J Cancer 1968;3:449-55.

${ }^{99}$ Izuo M, Okagaki T, Richart RM, Lattes R. Nuclear DNA content in hyperplastic lesions of cystic disease of the breast with special reference to malignant alteration. Cancer 1971;28:620-7.

${ }^{100}$ Izuo M, Okagaki T, Richart RM, Latters R. DNA content in "apocrine metaplasia" of fibrocystic disease of the breast. Cancer 1971;27:643-50.

${ }^{10}$ Hedley DW, Rugg CA, Taylor IW. Influence of cellular DNA content on disease free survival in stage II breast cancer. Proc Am Soc Clin Oncol 1984;3:121.

${ }^{102}$ Young RC, DeVita VT. Ovarian carcinoma: clinical trials, prognostic factors and criteria for response. In: Staquet MJ, ed. Cancer therapy: prognostic factors and criteria for response. New York: Raven Press, 1975;319-35.

${ }^{103}$ Dembo AJ, Bush RS. Choice of postoperative therapy based on prognostic factors. Int J Radiat Oncol Biol Phys 1982;8:893-7.

${ }^{104}$ Wake N, Hreshchyshyn, Piver SM, Matsui S, Sandberg AA. Specific cytogenetic changes in ovarian cancer involving chromosomes 6 and 14. Cancer Res 1980;40:4512-8.

${ }^{105}$ Atkin NB, Pickthall VJ. No 1 Chromosomes in 14 ovarian cancers: Heterochromatin variants and structural changes. Hum Genet 1977;38:25-33.

${ }^{106}$ Friedlander ML. The cytogenetic analysis of ovarian neoplasms. In: Hudson $\mathrm{CN}$, ed. Ovarian cancer. Oxford: Oxford University Press, (in press).

107 Atkin NB. Modal DNA value and chromosome number in ovarian neoplasia. A clinical and histopathologic assessment. Cancer 1970;27:1064-73.

${ }^{108}$ Atkin NB, Kay R. Prognostic significance of modal DNA value and other factors in malignant tumours based on 1465 cases. Br J Cancer 1979;40:210-21.

${ }^{109}$ Friedlander ML, Taylor IW, Russel P, Musgrove EA, Hedley DW, Tattersall MHN. Ploidy as a prognostic factor in ovarian cancer. Int J Gynecol Pathol 1983;2:55-63.

110 Friedlander ML, Hedley DW, Taylor IW, Russell P, Coates AS, Tattersall MHN. Influence of cellular DNA content on survival in advanced ovarian cancer. Cancer Res 1984;44:397-400.
"' Friedlander ML, Russell P, Taylor IW, Hedley DW, Tattersall MHN. Flow cytometric analysis of cellular DNA content as an adjunct to the diagnosis of ovarian tumours of borderline malignancy. Pathology 1984;16:301-6.

112 Friedlander ML, Taylor IW, Hedlwy DW, Tattersall MHN. The biological significance of cellular DNA content in ovarian cancer. Proc Am Assoc Cancer 1984; 25:34.

113 Bader S, Taylor HC, Engle ET. Deoxyribonucleic acid (DNA) content of human ovarian tumours in relation to histological grading. Lab Invest 1960;9:443-59.

${ }^{114}$ Hart WR. Ovarian epithelial tumours of borderline malignancy (carcinoma of low malignant potential). Hum Pathol 1977;8:541-9.

is Aure JC, Kolstad P. Clinical and histological studies of ovarian carcinoma, long term follow up of 99 cases. Obstet Gynecol 1971;37:1-9.

116 Weiss R, Richart R, Okagaki T. DNA content of mucinous tumours of the ovary. Am J Obstet Gynecol 1969;103:409-24.

1' Rotman M, Madu J, Boyce J. Prognostic factors in cervical cancer-implications in staging and management. Cancer 1981;48:560-7.

118 Atkin NB. Cytogenetic aspects of malignant transformation. In: Wolsky A, ed. Experimental biology and medicine. Basel, New York: Karger 1976;6: 1-171.

119 Atkin NB. Prognostic significance of ploidy level in human tumours. 1. Carcinoma of the uterus. J Natl Cancer Inst 1976;56: 909-10.

${ }^{120} \mathrm{Ng}$ ABP, Atkin NB. Histologic cell type and DNA value in the prognosis of squamous cell cancer of uterine cervix. $\mathrm{Br} J$ Cancer 1973; 28:322-31.

121 Jakobsen A. Prognostic impact of ploidy level in carcinoma of the cervix. Am J Clin Oncol (in press).

122 Jakobsen A. Ploidy level and short time prognosis of early cervix cancer. Radiother Oncol 1984; 1:271-5.

123 Jakobsen A, Kristensen PB, Poulsen HK. Flow cytometric classification of biopsy specimens from cervical intraepithelial neoplasia. Cytometry 1983;4:166-70.

124 Spriggs AI, Bowey CE, Cowdell RH. Chromosomes of precancerous lesions of the cervix uteri. New data and a review. Cancer 1971;27:1239-54.

${ }^{125} \mathrm{Fu}$ YS, Reagan JW, Richart RM. Definition of precursors. Gynecol Oncol 1980;12:220-31.

${ }^{126} \mathrm{Fu}$ YS, Reagan JW, Hsiu JG, Storaasli JP, Wentz WB. Adenocarcinoma and mixed carcinoma of the uterine cervix. I. Clinico-pathologic study. Cancer 1982;49:2560-70.

${ }^{127}$ Fu YS, Reagan JW, Fu AS, Janiga KE. Adenocarcinoma and mixed carcinoma of the uterine cervix. II. Prognostic value of DNA analysis. Cancer 1982;49:2571-7.

${ }^{128}$ Welch WR, Fu YS, Robboy SJ, Herbst AL. Nuclear DNA content of clear cell adenocarcinoma of the vagina and cervix and its relationship to prognosis. Gynecol Oncol 1983;15:230-8.

${ }^{129}$ Feichter GE, Hoffken H, Heep J, et al. DNA flow-cytometric measurements on the normal, atrophic, hyperplastic and neoplastic human endometrium. Virch Arch (Pathol Anat) 1982;398:53-65.

${ }^{130}$ Whitmore WF. The natural history of prostatic cancer. Cancer 1973;32:1104-12.

${ }^{131}$ Sprenger E, Volk L, Michaelis WE. The significance of nuclear DNA measurements in the diagnosis of prostatic carcinomas. Beitr Pathol 1974; 153:370-8.

${ }^{132}$ Bichel P, Frederiksen P, Kjaer T, Thommesen P, Vindelov LL. Flow microfluorometry and transrectal fine needle biopsy in the classification of human prostatic carcinoma. Cancer 1977; 40: 1206-11.

${ }^{133}$ Ronstrom L, Tribukait B, Esposti PL. DNA pattern and cytological findings in fine needle aspirates of untreated prostatic tumours. A flow-cytofluorometric study. Prostate 1981;2:79-88.

${ }^{134}$ Tribukait B, Ronstrom L, Esposti PL. Quantitative and qualitative aspects of flow DNA measurements related to the 
cytologic grade in prostatic carcinoma. Analytical and Quantitative Cytology 1983;5:107-11.

135 Tribukait B, Gustafson H, Esposti PL. The significance of ploidy and proliferation in the clinical and biological evaluation of bladder tumours: A study of 100 untreated cases. Br J Urol 1982;54:130-5.

${ }^{136}$ Lamb D. Correlation of chromosome counts with histological appearances and prognosis in transitional cell carcinoma of bladder. Br Med J 1967; i: 273-7.

${ }^{137}$ Sandberg AA. Chromosome markers and progression in bladder cancer. Cancer Res 1977;37:2950-6.

${ }^{138}$ Falor WH, Ward RM. Prognosis in well differentiated noninvasive carcinoma of the bladder on chromosomal analysis. Surgery Gynecol Obstet 1977;144:515-8.

${ }^{139}$ Fossa SD, Kaalhus O, Scott-Knudsen O. The clinical and histopathological significance of Feulgen DNA-Values in transitional cell carcinoma of the human urinary bladder. Eur $J$ Cancer 1977; 13:1155-62.

${ }^{140}$ Gustafson H, Tribukait B, Esposti PL. The prognostic value of DNA analysis in primary carcinoma in situ of the urinary bladder. Scand J Urol Nephrol 1982;16:141-6.

${ }^{141}$ Gustafson H, Tribukait B, Esposti PL. DNA pattern, histological grade and multiplicity related to recurrence rate in superficial bladder tumours. Scand J Urol Nephrol 1982;16:135-9.

${ }^{142}$ Gustafson H, Tribukait B, Esposti PL. DNA profile and tumour progression in patients with superficial bladder tumours. Urol Res 1982;10:13-8.

${ }^{143}$ Cooper EH, Williams RE, eds. The biology and clinical management of bladder cancer. Oxford: Blackwell Scientific Publications, 1975

${ }^{144}$ Gustafson H, Tribukait B, Brehmer-Andersson E. Detection of different DNA stem cell lines in a case of human bladder carcinoma. Acta Pathol Microbiol Scand [A] 1981;89:133-5.

${ }^{145}$ Busch C, Engberg A, Norlen BJ, Stenkvist B. Malignancy grading of epithelial bladder tumours. Scand J Urol Nephrol 1977;11:143-8.

${ }^{146}$ Bjelkenkrantz K, Herder O, Grontoft O, Stal O. Cytophotometric characterisation of WHO grades of transitional cell neoplasms. Path Res Pract 1982;174:68-77.

${ }^{147}$ Schwabe HW, Adolphs HD, Vogel J. Flow cytometric studies in renal carcinoma. Urol Res 1983;11:121-5.

${ }^{148}$ Bennington JL, Mayall BH. DNA cytometry on fourmicrometer sections of paraffin embedded human renal adenocarcinomas and adenomas. Cytometry 1983;4:31-9.

${ }^{149}$ Olszewski W, Darzynkiewicz Z, Claps ML, Melamed MR. Flow cytometry of lung carcinoma. A comparison of DNA stemline and cell cycle distribution with histology. Analytical and Quantitative Cytology 1982;25:90-4.

${ }^{150}$ Blondal T. Nuclear DNA in lung tumours. Uppsala, Sweden: Uppsala University Press 1982.

ist Adams LR, Dahlgren SE. Cytophotometric measurements of the DNA content of lung tumours. Acta Pathol Microbiol Scand $[A]$ 1968;72:561-74.

152 Johnson TS, Valdivieso M, Barlogie B, Jefferies D, Williamson $\mathrm{K}$, Keating M. Flow cytometric ploidy and proliferative activity in human small cell lung carcinomas: potential diagnostic and prognostic features. Proc Am Assoc Cancer Res 1983;488:124.

153 Whang Peng J, Kao-Shun CS, Lee EC, et al. A specific chromosome defect associated with human small cell lung cancer. Science 1982; 215:181-3.

154 Blondal T, Lindgren A. Fluorescence Cytophotometric Measurements of nuclear DNA in adenocarcinoma of the lung. Relation of proliferative activity and DNA ploidy to prognosis. Analytical and Quantitative Cytology 1982;3:225-32.

iss Blondal T, Bengtsson A. Nuclear DNA measurements in squamous cell carcinoma of the lung: A guide for prognostic evaluation. Anticancer Research 1981;1:79-86.

156 Spratt JS, Spjut HJ. Prevalence and prognosis of individual clinical and pathological variables associated with colorectal car- cinoma. Cancer 1967;20:1976-85.

${ }_{157}$ Tribukait B, Hammarberg C, Rubio C. Ploidy and proliferation patterns in colorectal adenocarcinomas related to Dukes' classification and to histopathological differentiation. A flow cytometric DNA study. Acta Pathol Microbiol Scand [A] 1983;91:89-95.

158 Wolley RC, Schreiber K, Koss LG, Karas M, Sherman A. DNA distribution in human colonic carcinomas and its relationship to clinical behaviour. $J$ Natl Cancer Inst 1982;69:15-22.

${ }^{159}$ Rognum TO, Thorud E, Elgjo K, Brandtzaeg P, Orjasaeter, Nygaard K. Large-bowel carcinomas with different ploidy, related to secretory component, $\operatorname{IgA}$ and CEA in epithelium and plasma. $\mathrm{Br} J$ Cancer 1982;45:921-34.

${ }^{160}$ Sondergaard K, Larsen JK, Moller U, Christensen IJ, Jensen KH. DNA ploidy-characteristics of human malignant melanoma analysed by flow cytometry and compared with histology and clinical course. Virchows Arch (Cell Pathol) 1983;42:43-52.

${ }^{161}$ Henry WM, Didolkar MS, Lopez R, Tomei LD. Tumour cell karyotypes in malignant melanoma. $J$ Surg Oncol 1979;11:31-8.

${ }^{102}$ Kawamoto K, Herz F, Wolley RC, Hirano A, Kajikawa H, Koss LG. Flow cytometric analysis of the DNA distribution in human brain tumours. Acta Neuropathol (Berl) 1979;46:3944.

${ }^{163}$ Lehmann J, Krug H. Flow through fluorocytophotometry of different brain tumours. Acta Neuropathol (Berl) 1980;49: 123-32.

${ }^{164}$ De Reuck J, Sieben G, Coster W, Roels H, Van der Eeken H. Cytophotometric DNA determination in human oligodendroglial tumours. Histopathology 1980;4:225-32.

${ }^{165}$ Mork S, Laerum OD. Modal DNA content of human intracranial neoplasms studied by flow cytometry. J Neurosurg 1980;53:198-204.

${ }^{166}$ Kajikawa H, Kawamoto K, Herz F, Wolley RC, Hirano A, Koss LG. Flow-through cytometry of meningiomas and cultured meningioma cells. Acta Neuropathol (Berl) 1978;44:183-7.

${ }^{167}$ Mark J. The human meningioma-a benign tumour with specific chromosome characteristics. In: German, ed. Chromosomes and cancer. New York: Wiley 1974:497-517.

${ }^{168}$ Kreicbergs A, Brostrom LA, Cewrien G, Einhorn S. Cellular DNA content in human osteosarcoma Aspects on diagnosis and prognosis. Cancer 1982;50:2476-81.

${ }^{169}$ Kriecbergs A, Boquist L, Borssen B, Larsson S. Prognostic factors in chondrosarcoma. A comparative study of cellular DNA content and clinicopathologic features. Cancer 1982;50:57783.

${ }^{170}$ Dahlin D. Pathology of osteosarcoma. Clin Orthop 1975; 111:23-32.

${ }^{171}$ Neville AM. The adrenal medulla. In: Symington T, ed. Functional pathology of the human adrenal gland. Edinburgh: Churchill Livingstone 1969:217-324.

${ }^{172}$ Lewis PD. A cytophotometric study of benign and malignant pheochromocytomas. Virchows Arch (Cell Pathol) 1971;9:371-6.

${ }^{173}$ Rowley JD. Do human tumours show a chromosome pattern specific for each etiologic agent. J Natl Cancer Inst 1974;52:315-20.

${ }^{174}$ Little CD, Nau MN, Carney DN, Gazdar AF, Minna JD Amplification and expression of c-myc oncogene in human lung cancer lines. Nature 1983;306:194-6.

Requests for reprints to: Dr ML Friedlander, Ludwig Institute for Cancer Research, Blackburn Building, University of Sydney, Sydney, NSW 2006, Australia. 